\title{
Striving to Maintainon a Holistic Nation: Preventing Quebec Sovereignty
}

\author{
KIMBERLEY GOSSE
}

Introduction

"Federalism is essentially a system of voluntary self-rule and shared rule [...] a binding partnership among equals in which the parties to the covenant retain their individual identity while creating a new entity."1 Canadian federalism illustrates how a political sub-unit such as a province, can maintain personal autonomy while contributing and recognizing its importance to the holistic entity. The federal and provincial governments'

${ }^{1}$ Kincaid in Good 2008, 3. 28 relationship is constitutional, as their division of powers is entrenched in our written Canadian constitution. However, ambiguity in legislature and a provinces belief of having a weak political identity can create tension among these levels of government. Historically, this has been an issue seen through the province of Quebec and the political turmoil experienced on each respective level of government. The Quebec referendums on sovereignty almost led to the destruction of a nation. The failure of the Meech Lake and Charlottetown Accords represented English 
Canadians and aboriginals disinterest in granting Quebec the luxury of being a "distinct society." This paper will discuss the failures of Meech Lake and Charlottetown Accords and why Canada is in a better position today because the constitutional amendments presented through these Accords were not ratified. Moreover, the paper will consider nonconstitutional measures taken since the demise of Quebec sovereignty to address the issues. First, political history prior to the Meech Lake Accord will be discussed. Secondly, the failure of Meech Lake will be considered. Thirdly, the issues surrounding the Charlottetown Accord will be investigated. Fourthly, the paper will present reasons why Canada is in a better political position because these accords were not ratified. Fifthly, non-constitutional measures will be demonstrated that have been created to address Quebec's legislative concerns.
Events leading up to Meech Lake

The Quebec independence movement was at the forefront of Quebec politics throughout the 1970s and early 1980s. René Lévesque, leader of the Parti Quebecois, led the independence movement in 1968 . He wanted to repatriate Quebec sovereignty. The Liberals in Quebec returned to power led by Robert Bourassa in 1970. The social climate in Quebec in the late 1960s and early 1970s had been highly explosive. It came to a head with the October Crisis in the 1970s when the Front de liberation du Quebec wanted Quebec sovereignty, which was vocalized through drastic measures. Through the Victoria Act in 1971, Prime Minister Pierre Trudeau attempted to patriate the constitution and to declare English and French as Canada's official languages. Although all 10 provinces and the federal government signed the agreement, Robert Bourassa premiere of Quebec, revoked the agreement after a few days because he felt Quebec's interests were not protected. Although 
originally unsuccessful, these changes were made legitimate through the Canada Act in 1982. The Parti Quebecois won power again in 1976 under René Lévesque. His success showed that the Quebec people supported his platform. This was the first time in political history had a province elected a party who was committed to secession. One of the first legislative movements by Lévesque and his government was enacting Bill 101, forcing nonAnglophone immigrants to enroll their children in French schools and called for French only commercial signs. ${ }^{2}$

The Quebec referendum of 1980 proposed this question to the citizens of Quebec: "Do you agree to give the Government of Quebec the mandate to negotiate the proposed agreement between Quebec and Canada?"3 Thus, if implemented the Quebec government would have control of issues surrounding sovereignty such

2 Michael S. Whitington and Glen Williams, Canadian Politics in the 1990's (Scarborough, Ontario: Nelson Canada, 1995), 93.

${ }^{3}$ Robert Young, Confederation in Crisis(Toronto: James Lormier \& Co., 1991), 13. as the administration of taxes and laws while still reaping the economical benefits from Canada and maintaining their currency.

Prior to the Constitution Act of 1982, any amendments to Canada's constitution had to go through the British parliament. At that time, Canada had been a country governed by the British North American Act until Prime Minister Pierre Trudeau convinced nine premiers to support constitutional reform, which included a Canadian amending formula. The Act approved two legislative changes: it patriated Canada's constitution, thus granting “Canada's parliament the power over future constitutional amendments", and rescinded British parliament's involvement in Canadian politics. ${ }^{4}$ Quebec did not sign the new constitutional agreement because they felt it did not give them the provincial autonomy they wanted. However, "legally and constitutionally, Quebec

\footnotetext{
${ }^{4}$ Marjorie Bowker, Canada's Constitutional Crisis (Edmonton: Lone Pine Publishing, 1991), 19.
} 
is nevertheless part of the

constitution." 5

\section{The Meech Lake Accord}

On April 30, 1987, federal and

provincial leaders met at a retreat on

Meech Lake in Quebec's Gatineau

Hills to amend the Canadian

constitution. This accord attempted to

gain Quebec's acceptance of the

Constitution act of 1982. Since the act,

Canadian politics had changed

immensely in the following years, at

both the federal and provincial level.

Under the leadership of Brian

Mulroney, the conservatives had

defeated the Liberals in 1984. In the

following year, the federalist Quebec

Liberal Party under the leadership of

Bourassa, came to power. Bourassa

formulated five constitutional

demands that would have to be met in

order for Quebec to sign the

Constitution Act of 1982. These

demands were: constitutional

recognition of Quebec as a "distinct

society"; restoration of Quebec's veto

5 Ibid., 18. on constitutional change; greater control over immigration; a role in selecting Supreme Court Justices and Senators from the province; and restriction of federal government's spending power in areas belonging to provincial jurisdiction. ${ }^{6}$

The Meech Lake Accord addressed five changes to the Canadian constitution. First, the "distinct society" clause recognized Quebec as a distinctive society in terms of both culture and language. It went so far as to recognize Canada's bilingual, bicultural heritage within and outside of Quebec and gave provincial governments the right to preserve these characteristics. For changes to be made to the constitution, it required the unanimous consent from parliament and all ten provincial legislatures. Second, the Accord also addressed issues dealing with immigration. Immigration now became a shared responsibility between the federal and provincial governments. It also guaranteed that Quebec would receive

${ }^{6}$ Good, Kristin. 2008. Quebec-Canada Relations Unit, September 22, 2008, 17. 
an annual number of immigrants based on its share of the population. Third, the Accord suggested an alternate format to select Supreme Court of Canada judges. When a vacancy came open, the premieres could submit names and the prime minister would have to make his choice from the given list. Before the Accord, the prime minister was under no obligation to take a premieres choice into consideration. Fourth, all provinces were given a role in selecting Supreme Court justices and senators and entrenched Quebec rights to three Supreme Court Justices. In the case of Quebec, since it had the right to three of the nine Supreme Court justices appointed from that province, only the Quebec premiere could submit names whenever a Quebec vacancy came open. Finally, provinces were also given the right to opt out of new national programs with compensation as long as they established similar programs that were in keeping with national plans. " "In order to become

${ }^{7}$ Ibid., 18. law, the Accord had to be ratified by Parliament and the legislatures of all the provinces in accordance with Section 41 of the Constitution Act."8 These legislative demands on behalf of Quebec were overwhelming for English Canadians. They were opposed to the idea of defining Quebec as a "distinct society." "Not only was the process by which the accord had been arrived at illegitimate, the substance of the accord itself was at odds with the conception of the federation that had achieved dominance in English Canada with the patriation of the constitution."9 The distinct society clause attacked "the essence of the constitutional principles that Canadians held dear their equality as citizens with constitutional rights under the charter and the equality of the provinces." 10 The clause would have created asymmetrical federalism. Manitoba and Newfoundland were keys in the

\footnotetext{
${ }^{8}$ Ibid., 19.

9 Raymond B. Blake, Transforming the Nation: Canada and Brian Mulroney (Montreal: McGill-Queen's University Press, 2007), 86.

${ }^{10} \mathrm{Ibid}$.
} 
demise of Meech Lake. Aboriginal

MLA Elijah Harper of Manitoba, refused to support the Accord based on the fact that there was no First Nation representation within its five major conditions. Along with Harper's refusal, Clyde Wells Premier of Newfoundland, first supported the agreement but learning of Harper's refusal, he withdrew his support and adjourned the Newfoundland legislature before a free vote could be held. ${ }^{11}$ Also the new Liberal Leader Frank McKenna in New Brunswick did not support the Accord and Quebec Liberal Premier Bourassa's use of the notwithstanding clause to "protect its signs legislation against the Charter." This elicited disapproval from English Canada. It has been stated that section 38 (1) of the 1982 Act which created the new amending formula, played a role in McKenna's decision. "Section 38 (1) allowed for parliamentary debate and legislative committee hearings, public forums,

11 Peter H. Russell, Constitutional Odyssey (Toronto: University of Toronto Press Inc, 1993), 151. and other forums of ratifications." 12 It allowed McKenna to hold public forums on the accord which ultimately slowed the ratification process and gave opponents the chance to find support against it. 13

The public had numerous concerns over the Accord. In the midst of attending to constitutional amendments, the public began to view the process as " 11 white men meeting in the middle of the night in secret to rewrite Canada's constitution"14, making decisions without consulting the Canadian people. They saw themselves as having no part in the process. Canadian's expressed the emphasis on having a "citizen's constitution," 15 feeling that too much information was being withheld. This catalyzed a "decline of deference"16 as the public resented their lack of involvement in political issues.

\footnotetext{
${ }^{12}$ Michael S. Whittington and Glen Williams, Canadian Politics in the 1990s (Scarborough, Ontario: Nelson Company, 1995), 325.

13 Ibid.

14 Ibid. 326.

15 Good, Kristin. 2008. Quebec-Canada Relations Unit, September 22, 2008, 27. 16 Ibid.
} 
Moreover, women's organizations believed the "distinct society" clause would compromise their Charter rights. There was growing concern and emphasis by minority groups for non-territorial representation in the fear that they would be lost in their demographics. In addition, Former Prime Minister Pierre Trudeau came out of retirement and condemned the Accord by stating, if ratified; it would "render the Canadian state totally impotent." 17 Despite vocal opposition, the Meech Lake Accord was almost ratified. The Canadian amending formula declared that once constitutional amendments are presented and passed on behalf of one province, there is a three year deadline for the federal government and all provinces to ratify the amendments for a legitimate legislative change to occur. Thus the deadline for ratification was June 23, 1990 after the first province, Quebec,

\footnotetext{
17 Rhonda Parkinson, Road to Meech Lake: Quebec and the Constitution, 14 September 2007, $<$ www.mapleleafweb.com/features/meec h-lake-accord-history-overview $>,(4$ November 2008), 5.
}

formally supported the changes three years prior. Within a year, parliament and eight provinces had approved the ratification. However, the Meech Lake Accord was terminated as Manitoba and Newfoundland failed to produce legislature on June 23, 1990.

According to Roger Gibbins, the general public mood of Canadian's leading up to the Charlottetown Accord was one of "sourness or nastiness." 18 He felt that Canada had lost faith in politicians and the existing political institutions. There was a resistance to renewed constitutional negotiations. Based on a $\mathrm{CBC} /$ Globe and Mail poll, Canadian people were asked what they thought the likelihood would be of Quebec eventually separating from Canada. ${ }^{19}$ The results of the poll showed that Canadians did not feel that Quebec would separate from Canada. Especially in the West the percentage was very low: 6 percent on the Prairies, 10 percent in British

\footnotetext{
${ }^{18}$ Robert Young, Confederation in Crisis (Toronto: James Lormier \& Company, 1991), 22-23.

19 Ibid.
} 
Columbia and 10 percent in Ontario. ${ }^{20}$

The results showed that Canadian's were willing to call Quebec's bluff.

\section{The Charlottetown Accord}

The Charlottetown Accord was the end result of five years of numerous meetings on constitutional reform involving the federal, provincial and territorial government and representatives of Aboriginal peoples. After the failure of Meech Lake, Quebec was angry and felt rejected which intensified their wishes for separation. The issues involved in the Charlottetown Accord were similar to Quebec's demands seen in Meech Lake, however with slight modifications. The "distinct society" issue was again on the table. This idea was reinforced through the Canada Clause "which incorporated a distinct society clause as well as another clause authorizing the legislature and government of Quebec to preserve and promote the distinct society of

20 ibid.
Quebec."21 Another issue addressed in the Charlottetown accord was Quebec's potential veto on 'reform on national institutions'. Moreover if the accord was ratified, Quebec would be given 25 percent of representation in the House of Commons. This was upsetting to the other provinces as a "25 percent guarantee for Quebec was not in line with demographic trends." 22 In particular, Alberta and British Columbia would be less represented in the senate. ${ }^{23}$ This was seen as a necessity on behalf of the Quebec government as Bourassa was uneasy with the Triple E senate proposal, which strived for better regional representation for western Canada. The aboriginal people were appalled that the federal government was willing to grant Quebec the status of being a "distinct society" going beyond

${ }^{21}$ Raymond B. Blake, Transforming the Nation: Canada and Brian Mulroney (Montreal: McGill-Queen's University Press, 2007), 282. ${ }^{22}$ Good, Kristin. 2008. Quebec-Canada Relations Unit, September 22, 41. ${ }^{23}$ Richard Johnson, Neil Nevitte and Elizabeth Gidengil, The Challenge of Direct Democracy: The 1992 Canadian Referendum, (Montreal: McGill-Queen's University Press. 
the definition in the Meech Lake Accord. Although the accord also called for two aboriginal representatives in the House of Commons and the recognition of aboriginal rights as a "third level of government", this was deemed not enough by the aboriginal people. The Constitution Act of 1982 recognized that further "identification and definitions of the rights" of aboriginal peoples was a piece of unfinished constitutional business which must be addressed. ${ }^{24}$ Aboriginal groups wanted self-government. Aboriginal leaders regarded the right of their peoples to govern themselves as a moral right that they had long before Europeans arrived, and one they had never relinquished. ${ }^{25}$ They also strongly believed it must be recognized in the constitution as coming from their inherent right to self-government, not from the good well of Canadians and the government.

Quebec Sovereignty: Why Canada would have been worse off

24 Peter H. Russell, Constitutional Odyssey (Toronto: University of Toronto Press Inc, 1993),130.

25 Ibid. 131.
Sir John A. MacDonald once said, "We are a great country, and shall become one of the greatest in the universe if we preserve it; we shall sink into insignificance and adversity if we suffer it to be broken." 26 As the quote implies, a separation of a province from Canada would reduce its power on the global scene. This in turn could leave Canada vulnerable to the United States in a number of ways. Previous contracts regarding national security and free trade, or even civil unrest could give the United States the chance to become a major player in Canada's national issues. Hypothetically, if there was great tension between Canada and Quebec leading to civil unrest, the United States could potentially send troops to intervene, under the pretense of protecting its own borders. If the federal government paid out substantial amounts of money to appease the remaining provinces, how then would Ottawa be able to pay for

\footnotetext{
${ }^{26}$ J.L.Granatstein and Kenneth McNaught, English Canada Speaks Out (Toronto: Doubleday Canada Limited, 1991),105.
} 
its defense bill? Would Canada's air space be absorbed by the United States? Many of these issues would lead one to believe that Canada could become part of the United States. Potentially having another country within Canada would compromise the defense of our nation, creating problems around the border of Canada and Quebec if civil unrest was to transpire. In addition, Canadian allies may now question the contribution Canada and Quebec would make to the North Atlantic Treaty

Organization. ${ }^{27}$

If Quebec had successfully separated from Canada, numerous economic repercussions would have followed. According to the December 1996 report of the Committee on the Evolution of Canadian Federalism, compared to other provinces Quebec's economy is the most dependent on interprovincial trading. ${ }^{28}$ It exports to other provinces more than it imports.

${ }^{27}$ Robert A. Young, The Struggle for Quebec (Montreal: McGill-Queen's University Press, 1999), 139. ${ }^{28}$ Committee on the evolution of Canadian Federalism, Quebec's Identity and Canadian Federalism (Ottawa: Liberal Party of Canada, 1996),63.
If relations were tense between Canada and Quebec, then Canadian provinces would have to look for alternate markets for their products. In addition, the stock market could decline sharply, our dollar could reach record lows, and our interest rates could rise. Obviously this could concern foreign investors and would dwindle their confidence in the Canadian economy. ${ }^{29}$ Americans in particular have billons of dollars invested in Canada and millions of dollars depended on trade with this country $^{30}$ and this in itself may put pressure on Canada to resolve political tension.

Historically the Atlantic Provinces have depended on federal payouts (equalization payments or unemployment assurance benefits) to mitigate "regional economical disparities" 31 according to Granatstein and McNaught. Because of this, they have always advocated for a strong central government in order to keep

\footnotetext{
29 Ibid. 62.

${ }^{30}$ Ibid.139-40.

31 J.L. Granatstein and Kenneth McNaught, English Canada Speaks Out (Toronto: Doubleday Canada Limited, 1991), 116.
} 
the money coming in. Because of the reallocation of federal resources following Quebec's secession, these provinces would be potentially vulnerable to economic crisis without adequate support from the federal government. It is also important to note that the Atlantic provinces would be physically separated from the rest of Canada which could lead them to question their political identity.

A sovereign Quebec would result in a re-evaluation of political legislature. According to Marjorie Bowker, the rest of Canada could be left with no constitutional structure. ${ }^{32}$ There would be a need to evaluate the constitution -technicalities in our written constitution would have to be amended upon the dismissal of a subunit from its central government. This would result in many tedious, but important constitutional changes.

Non-constitutional Measures implemented regarding the Accord's Issues

32Marjorie Bowker, Canada's Constitutional Crisis (Edmonton: Lone Pine Publishing, 1991),112.
After the referendum of 1995 there was great pressure placed on Ottawa to resolve the sovereignty issue. The Federal government tried to do this in numerous ways. Ottawa tried to fulfill the commitments they had made to Quebec at the end of the referendum campaign. Two non-constitutional measures put forth by Parliament were Plan A and Plan B.

\section{The basic objective of Plan A} was to "entrench a distinct society clause." 33 The approach taken was to reconfirm the importance of Quebec's role in the federation. Quebec accounts for a high percentage of the diversity present in Canada, and without their contribution, Canada would be less developed in terms of culture and language. Under this plan Canada would declare and celebrate Quebec as a distinct society within our country. Some of the Premieres believed Plan A was granting special status to Quebec and disapproved of asymmetrical federalism as they believed Canada

\footnotetext{
33 Robert A. Young, The Struggle for Quebec (Montreal: McGill-Queen's University Press, 1999), 94.
} 
should continue to practice equality among provinces. Since Ottawa could not get the consensus among Premiers of Alberta, BC, and Ontario the federal government went alone and introduced into parliament a resolution to recognize Quebec as a distinct society. Another element of Plan A was to decentralize some of the federal power and for Ottawa to restrict its spending power. Other initiatives included the federal government opting out of job training and greater intergovernmental communication. The government had taken out full page adds in Quebec and sent pamphlets to each Quebec household notifying individuals how they had met their referendum commitments.

Another piece of legislation addressing Quebec secession was Plan $\mathrm{B}$, which called for a series of initiatives to clarify the process of secession and some of its implications. This tactic stressed the ambiguous process of secession itself. Other groups for example, aboriginals, municipalities or regional municipalities in Quebec could also separate from Quebec. In the words of Stéphane Dion, "if Canada is divisible, Quebec is divisible too. If I give myself a right, I can not stop others from exercising the same right." 34 Three questions stemmed from the possibility of secession: Under the constitution, can [...] the government of Quebec effect the secession of Quebec from Canada unilaterally? Is there a right under international law [...] to effect the secession of Quebec from Canada unilaterally? In event of conflict, between domestic and international law [...], which would take precedence in Canada? ${ }^{35}$ In the end, it was left to the political process i.e. Supreme Court of Canada to address the issue. The courts decided Quebec would be acting against the accordance of the law (constitutionally and internationally) if they were to unilaterally secede. However, it was also concluded that "there is a constitutional obligation for the rest of

\footnotetext{
${ }^{34}$ Robert A. Young, The Struggle for Quebec (Montreal: McGill-Queen's University Press, 1999),102. ${ }^{35}$ Robert A. Young, The Struggle for Quebec (Montreal: McGill-Queen's University Press, 1999), 108.
} 
Canada to negotiate with Quebec, should a 'clear majority' on a clear question' express the will to secede." ${ }^{6}$

Collaborative federalism began to be exercised after the descent of the Meech Lake and Charlottetown Accords in an attempt to narrow the legislative conflict between the federal parliament and provincial autonomies. The Agreement on Internal Trade in 1994 was the beginning of governmental collaboration through non-constitutional means. This stated that when applicable, national standards would be created through intergovernmental collaboration. ${ }^{37}$ National standards were important to central Canada as well as in adhering to the specific needs of each province. Other initiatives taken were Ottawa's pledge to restrict its spending power. An example of this would be the "Framework to Improve the Social Union for Canadians" which was established in 1999 with emphasis on

${ }^{36}$ Good, Kristin. 2008. Quebec-Canada Relations Unit, September 22, 2008, 58. 37 Ian Robinson and Richard Simeon, The Dynamics of Canadian Federalism (Peterborough, Ontario: Broadview Press), 120. a social union between the two levels of government. "Social union" refers to "the complex set of intergovernmental agreements through which the major elements of social policy: health, postsecondary education, and welfare" 38 were formulated. Provincial governments would be notified in advance of new programs being implicated. More importantly, the federal and provincial governments would team up to distinguish items of national precedence with the federal government acknowledging they would not implement a new program without the majority of the provinces consent.

In order for collaborative federalism to exist, all parties involved must show reciprocated respect for one another with the well being of all Canadians to be considered. Thus the "emphasis is on equal partnership, not federal leadership."39

Additional measures taken nonconstitutionally by the federal government to address the issues tackled in the Meech Lake and

\footnotetext{
38 Ibid.

${ }^{39}$ Ibid. 121
} 
Charlottetown Accords was Stephen

Harper's introduction of open

federalism in which he strived to have

a more balanced federal system. He

sought to support provincial autonomy

while attending to matters of national importance.

\section{Conclusion}

Quebec separatism has been a key issue in Canadian politics since the 1970s. The issue has been addressed through numerous legislative initiatives primarily the Meech Lake and Charlottetown accords. Although these propositions failed, the federal government has made continuous attempts to accommodate different political identities within Canada such as the French majority in and outside of Quebec, Aboriginal people, and English Canadians. Other legislative strategies put forth by parliament would include Plan A, Plan B, and SUFA. Furthermore, our political system has emphasized different approaches to executing federalism. For example, collaborative, open and asymmetrical federalism have tried to integrate the needs of the provinces (especially Quebec), with the aspirations of non-territorial groups. Yet, as seen historically throughout Canadian politics, it is unlikely that Quebec, the west or Aboriginal people will give up their own political agendas to look at the bigger picture of the welfare of all Canadians.

\section{Works Cited}

Blake, Raymond B. Transforming the Nation: Canada and Brian Mulroney. Montreal: McGill-Queen's University Press, 2007.

Bowker, Marjorie. Canada's Constitutional Crisis: Making Sense of It All. Alberta: Lone Pine Publishing, 1991.

Committee on the Evolution of Canadian Federalism. Quebec's Identity and Canadian Federalism: Recognition and Interdependence. Ottawa: Liberal Party of Canada. 
Granatstein, J.L., and Kenneth McNaught. English Canada Speaks Out.Toronto: Doubleday Canada, 1991.

Johnson, Richard, Neil Nevitte and Elizabeth Gidengil. The Challenge of Direct Democracy: The 1992 Canadian Referendum. Montreal: McGill-Queen's University Press, 1996.

Kincaid, John. Handbook of Federal Countries: 2002. Introduction, Montreal and Kingston: McGill-Queen's University Press, 2002.

Parkinson, Rhonda. Road to Meech Lake: Quebec and the Constitution. 14 September 2007. <www.mapleleafweb.com/features/meech-lake-accordhistory-overview>, (4 November 2008).

Robinson, Ian and Richard Simeon. "The Dynamics of Canadian Federalism." "In" Canadian Politics (4th edition). Eds. J. Bickerton and A. Gagnon. Peterborough, Ontario: Broadview Press, 2004.

Russell, Peter H. Constitutional Odyssey Toronto: University of Toronto Press Inc, 1993.

Whitington, Micheal S. and Glen Williams. Canadian Politics in the 1990's Scarborough, Ontario: Nelson Canada, 1995.

Young, Robert. Confederation in Crisis. Toronto: James Lormier \& Company, 1991.

Young, Robert A. The Struggle for Quebec: from Referendum to referendum? Canada: McGill-Queen's University Press, 1999. 